\title{
The Division of Household Work in Moroccan Amazigh Male-breadwinner Families with Young Children
}

\author{
Bouchra El Kemma
}

Cadi Ayyad university, Morocco

Received: 19 Feb 2021; Received in revised form: 25 Apr 2021; Accepted: 16 May 2021; Available online: 30 May 2021

(C)2021 The Author(s). Published by Infogain Publication. This is an open access article under the CC BY license (https://creativecommons.org/licenses/by/4.0/).

\begin{abstract}
No previous research tackles the issue of household work in the Moroccan Amazigh context. In Morocco, household work is still restricted to Amazigh women. Wives perform a far greater proportion of household work than husbands. Moroccan Amazigh Couples may share household work, but not specific tasks. Household tasks have remained highly sex-typed and are shared quite unequally among most, if not all, married couples. In this regard, it is worth mentioning that the gender-based inequality in the division of household work is a hot issue that attracts the attention of most family research scholars. This study adds extra depth to further our understanding of the lopsided division of household work by hypothesizing that childhood socialization might influence the way male-breadwinner couples divide household work. Parents' domestic work practices may have a great impact on the type of tasks undertaken by husbands and wives at the time when they were male and female children. Results indicate that childhood socialization and spouses' gender ideologies have a great impact on the actual division of household work among male-breadwinner couples. Changes in the traditional division of labor are likely to come from couples experiencing paternal domestic involvement during childhood.
\end{abstract}

Keywords-household work, Amazigh male-breadwinner couples, unequal division of household tasks.

\section{INTRODUCTION}

History shows that Moroccan women have gained equal opportunities in almost every field such as education, professional work, politics, familylife and so on. For this reason, our king Mohammed VI assigned a royal committee of virtuous scholars and experts to make changes in the Code of Personal Status with the aim of preparing a new "Mudawana" in harmony with the teachings of Islam (the Family Code, 2010, p. 10). This "Mudawana" has really improved women's status and then guaranteed their rights by strengthening their position in the private sphere. It is true that the new Family Code

${ }^{1}$ The Family Code, generally known as "Mudawana", was ratified by the two houses of parliament and published in the official journal in 5 February 2004. It brought fundamental changes; this reform puts Moroccan women on equal legal footing with men. It has introduced a range of measures that enhance women's legal status in marriage, divorce, polygamy, inheritance, and child custody. revolves around equality between spouses, family equilibrium and the protection of children. However, the impact of patriarchy, tradition, illiteracy and ignorance still prevents women from getting their full rights or reporting crimes against them, such as rape, sexual exploitation, and domestic violence.

Moroccan women are still facing gender inequality and bias at home.Amazigh women in Malebreadwinner households undergo gender inequality in the private sphere (i.e. at home) as there is still sex segregation of household work. The gender division of household work in the home is a living proof of the existence of gender stratification. Wives still do all or most of the housework and childcare tasks, which are believed to be feminine tasks. Wives take significantly more responsibility than their husbands who still do relatively little domestic labor. In an attempt to explain the hidden factors behind the unequal division of household tasks 
among Male-breadwinner couples, this paper examines childhood influences on husbands' and wives' behavior in the domestic sphere. If household work is unequally distributed between parents during the process of socialization, then spouses as children may adopt traditional roles. Most importantly, husbands' allocation of housework is predicted to be strongly connected with fathers' participation in domestic duties during husbands' childhoods. Like wives, husbands may imitate their fathers as the latter serve as role models and belong to the same gender. Following this line of reasoning, if spouses acquire characteristics via emulating their parents, they are bound to demonstrate their parents' specific behavior.

\section{REVIEW OF LITERATURE}

\subsection{Household Work Definitions}

Household work is defined in a simple way. To elaborate, most studies use household work to refer to both housework and childcare (Poortman \& Van Der Lippe, 2009; Erickson, 2005). Here, it is worth mentioning that household work is variously labeled unpaid work, family labor, household labor and domestic work. It is renamed unpaid work because "no one gets paid for work they do for themselves and their families" (Delphy, 1984, p. 88). Delphy (1984) has mentioned that the unpaid work means all the tasks done within the confines of the homecooking, washing, ironing, sewing, shopping, cleaning, servicing, and caring of children. In this regard, household work is defined as "the unpaid labor performed within the household" (Brines, 1994, p. 656). Finally, one cannot help noticing that household work has attracted scholars' attention, but has been defined in a very narrow sense.

\subsection{Household Work Forms}

Household work is rarely defined explicitly. Household work has been defined as a set of physical tasks such as cooking, cleaning, shopping and laundry, but its mental and emotional dimensions have been mostly missing (Eichler \& Albanese, 2007). There are very few studies which have defined household work in a clear sense (Dodson \& Dickert, 2004; Shelton and John, 1996). To illustrate, Dodson \& Dickert (2004) have referred to it "as physical duties, caregiving and household management responsibilities" (p. 318).So, it is evident that despite the fact that the concept of household work includes child minding, "household management", "emotional work" and various kinds of household labor, most household work studies have neglected these overlapping types of work from study (Coltrane, 2000, p. 1211). This indifference to childcare, emotional work and other integral parts of household work has continued to be a major shortcoming in family research.
Housework is considered to be one of the major forms of household work. Researchers have divided housework into two major categories, naming each one several terms. To start with, the first category is to do with the five major household tasks that are considered to be the most time consuming-cooking, washing-up, house cleaning, shopping, and laundry - and the second category is concerned with such tasks as household repairs, gardening, driving people and paying bills (Coltrane, 2000).In this regard, several terms have been coined by researchers to describe each category. The first category of tasks that require frequent attention has been labeled "nondiscretionary", "mundane", "repetitive", "onerous", "unrelenting", "boring", "routine housework", or simply "housework", whereas the second has been termed "residual", "occasional", and "other" (ibid., p. 1211). Besides, some researchers use nomenclature focusing on the character of the tasks themselves. For instance, Baxter (1997, pp. 309-310) differentiates the two kinds of chores by naming them "indoor" and "outdoor" tasks. Other scholars use gender to distinguish between the two types of tasks, calling the "routine housework" chores (cooking, cleaning and shopping) "female-dominated", "femalestereotypic", "female gender-typed", "traditionally feminine", "feminine" (Coltrane, 2000, p. 1212), "female sex-typed", or "female oriented" (Blair \& Lichter, 1991, p. 94). Conversely, such less frequent tasks as household repairs, mowing the lawn, and taking care of cars are labeled "masculine", "male", "male-dominated", or "maletype (Coltrane, 2000, p. 1212). Here, it is significant to mention that cultural beliefs about appropriate tasks for men and women do lead researchers to apply gendered labels to these activities, the fact meaning that gender affects household labor allocation. To conclude, as it seems, scholars have coined many phrases to describe household labor tasks.

Childcare, as another form of household work, is sometimes incorporated into the household work and sometimes not. The concept of "shared parenting" emphasizing the idea that "both parents had to...split the division of childcare tasks" is hardly seen in real life (Ehrenberg, Gearing-Small, Hunter, \& Small, 2001, p. 143).As a matter of fact, wives in dual-earner families significantly assume more responsibility than do their husbands. The latter are rarely involved in tasks as diapering and bathing. So, wives do more parenting activities than husbands. In this respect, six are the types of activities in which husbands as fathers are involved with children-"personal care activities", "play and 
companionship activities"2, "achievement-related activities"3, "household activities"4, "social activities"5 and "other activities"6(Yeung, Sandberg, Davis-kean \& Hafferth, 2001, p. 141). Personally speaking, I am concerned only with the first type of activities (personal care activities) as it is culturally seen to be women's work. Personal care activities involve "care the child receives from the fathers such as bathing, changing, and grooming, as well as meals together at home and away from home" (ibid., p. 141). Fathers are rarely engaged in such activities as washing, dressing, feeding and medical care. On the contrary, fathers are likely to "show higher involvement in play activities than do mothers" (Hossain \& Anziano, 2008, p. 110). Likewise, Robinson and Godbey (as cited in Yeung, Sandberg, Davis-kean \& Hafferth, 2001, p. 138) have come to the conclusion that "most of the time men spent with children was in the form of interactive activities, such as play or helping with homework, rather than in the custodial cleaning and feeding that are the mother's domains." So, it appears obvious that father's participation percentage in personal care activities is very low, as this kind of work is considered to be women's work. Women are the primary caregivers of children. As far as this study is concerned, it is not going to treat childcare and housework independently, and it will measure and analyze both of them by collecting more accurate data on the two kinds of tasks. It will seek to know who does the parenting in dual-earner families; who is more involved in parenting, the mother or the father? Or do they equally share child-rearing responsibilities?

Apart from housework and childcare, adult care, emotion care and household responsibilities are regarded to be other forms of household work. To begin with, having a quick look at household work as being "the routine activities that feed, clothe, shelter, and care for both children and adults" (Coltrane, 2000, p. 1209), one cannot help noting that adult care is seen as one aspect of domestic work. However, adult care is usually excluded and neglected on the part of scholars, as opposed to childcare which is seen as part of household work (Eichler $\&$ Albanese, 2007). Adult care is to do with "care for adults - adult children, parents, spouses and friends" (ibid., p. 244). To my mind, it goes without saying that adults who suffer from medical problems and physical abilities, for instance, are in constant need of help and care. That is why it does not seem to make sense that childcare is included, but adult care is overlooked. Hence, I totally agree with Ishii-Kuntz and Coltrane (as cited in Eichler \& Albanese, 2007, p. 243) who have suggested that household labor and care work (childcare or adult care) "shouldn't be treated as conceptually distinct activities." As for emotion work, it has been excluded from household work studies as well (Erickson, 1993).Erickson asserts that it "is undoubtedly an artificial separation to differentiate housework, or instrumental tasks, from emotion work tasks" (p. 898). Emotion work can include such things as comforting, support, advice, resolving conflicts, and handling crises (Eichler \& Albanese, 2007). Eichler \& Albanese have concluded that women provide emotional support more than men and carry the emotional burden of their families. Furthermore, household management or planning, as another aspect of domestic labor, has been passed over in studies. Household management is invisible work, as opposed to cleaning up and cooking which are visible; the thinking process precedes household labor itself (Thompson and Walker, 1989; Eichler\& Albanese, 2007). Researchers pay attention only to the physical part of household work by noting the time taken to do the shopping or cooking for instance, but ignore the time and thought given to making the shopping list or searching for a recipe (Eichler\& Albanese, 2007) . In brief, these aspects of household work are rarely tackled by most scholars of family research.

Looking at the various forms of domestic labor raised above, I have devised a diagram (Figure 1) providing an oversimplified picture about domestic chores. I am in agreement with Eichler and Albanese (2007) who have criticized other scholars dealing with each form of household work in isolation and hence have given a vivid description of household labor, including childcare, emotion work, and household management. Nevertheless, I will limit the scope of my study and emphasize only two forms of domestic labor: housework and childcare. Also, from now on, I will use the phrases household work, household labor, family work, unpaid work, domestic work interchangeably to denote housework and childcare.

\footnotetext{
${ }^{2}$ Play and companionship activities "include both active and passive play and other types of leisure events."

${ }^{3}$ Achievement-related activities "include time spent studying, doing homework, reading, and in educational lessons."

${ }^{4}$ Household activities "include housework, shopping, and the time the child spends caring for other children."

${ }^{5}$ Social activities "include visiting, household conversations, religious activities, and participation in other social events." ${ }^{6}$ Other activities "include time in school and day care, sleep time, and other activities not included in the previous five categories."
} 


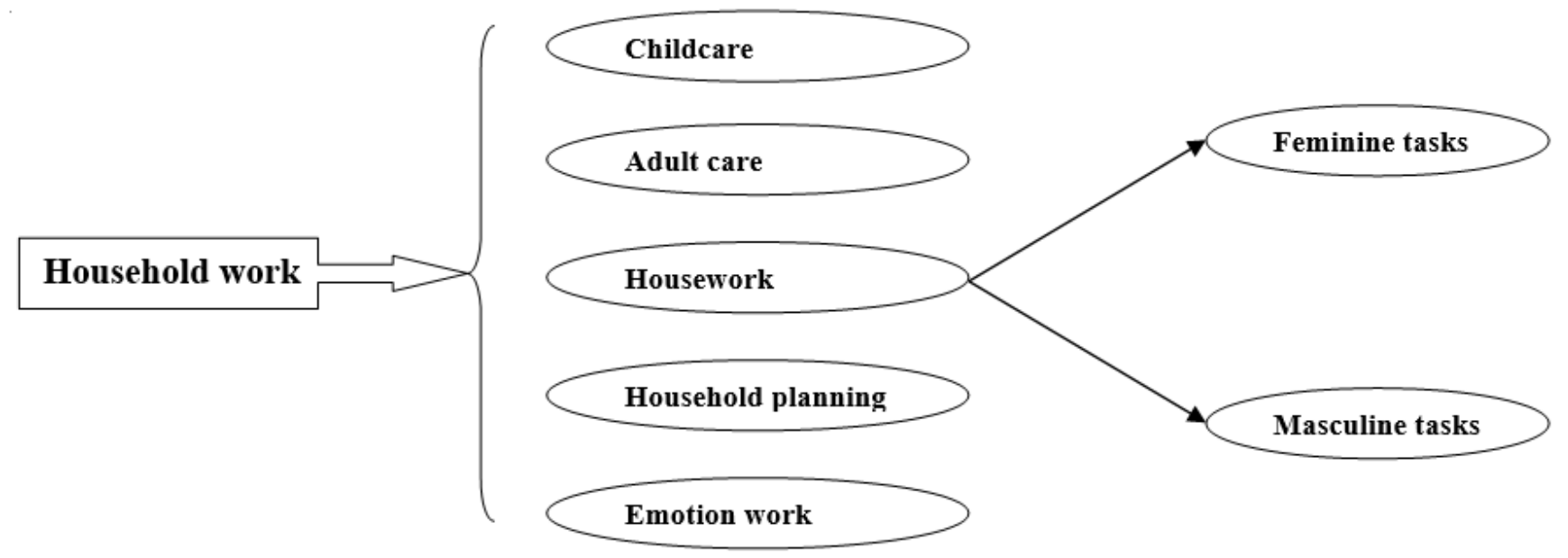

Fig.1: The various forms of household work.

In summary, the inclusion of mental and emotional dimensions in household work is missing in most family research studies. To understand household work, one should go beyond looking at it as physical tasks-preparing meals, doing the laundry, cleaning the house, shopping for groceries, and doing the dishes. Instead, it actually consists of all physical, mental, and emotional tasks. Such tasks that have to do with the mental and emotional aspects as "planning family special events", "maintaining finances", "attending school trips", "teacher meetings", "arranging for and attending health appointments", "emotion support for family", and so on so forth do not get most scholars' attention (Eichler \& Albanese, 2007, p. 237). Similarly, Zick (1996) insists that "housework can be both physically and mentally demanding" (p. 395). The task of cooking, for instance, is based on mental activities that are indispensable in providing a meal.

\subsection{Gender ideology}

This approach hypothesizes that role-traditional couples are to exhibit a gender-based division of household labor, while couples holding egalitarian gender roles are supposed to enjoy equal sharing of domestic labor (Blair \& Lichter, 1991). Husbands holding traditional roles are supposed to work outside home and earn a living, while wives are expected to do domestic tasks (Kamo, 1988). Hiller (1984)(cited in Blair \& Lichter, 1991, p. 94) proposes that "the more deeply one or both partners have internalized a traditional sex role, the more likely the wife will be solely responsible for family work." So, it is expected that the more traditional a husband is, the less family work he does. The gender ideology perspective argues that attitudes regarding gender roles influence domestic labor performance (Greenstein, 1996). That is to say, spouses with liberal attitudes about gender and marital roles are hypothesized to divide domestic work more equitably than spouses with traditional attitudes. This means that couples holding more traditional and conservative beliefs will do the lion's share of family work and exhibit a more segregated division of labor, while couples holding egalitarian gender ideologies will have an equal division of household labor.

Later studies have found that men and women with liberal gender ideologies are more likely to share housework equally, and that men and women with traditional gender ideologies experience a gendered division of labor (Greenstein, 2000). The findings of studies employing the gender ideology perspective have been consistent with the approach prediction (e.g., Blair \& lichter, 1991; Kamo, 1988; Greensten, 1996). Most studies find that men's and women's sex-role attitudes are important determinants of household labor performance (Blair \& Litcher, 1991; Kamo, 1988). Nevertheless, some researchers find no link between men's and women's attitudes about gender roles and housework allocation (Greenstein, 2000). For example, Poortmanand Tanja (2009) come to the conclusion that to understand the gendered meaning of household labor, one must look at personal and specific attitudes of men and women rather than their general and abstract gender ideologies. They believe that a person's specific attitudes towards household labor do add more weight to grasp the division of domestic labor, rather than their general attitudes towards men and women's roles. It is also stated that “contrary to people's more general views on how men and women ought to divide tasks (i.e., gender ideology), these attitudes reflect personal feelings and thoughts about performing household labor and the importance they attach to it, in other words their personal evaluations" (cited in 
Poortman and Tanja, 2009, p.527). Poortman and Tanja themselves refute gender ideology approach declaring that abstract attitudes are weak predictors of behavior in comparison with specific attitudes. Personal attitudes probably reflect more the gendered meaning of domestic work and hence may be stronger predictors than gender ideology.

The gender ideology perspective assumes that "household labor is intertwined with beliefs about certain behaviors being typically male or female" (cited in Poortman \&Tanja, 2009, p. 526). For instance, cooking, cleaning, washing up, doing the laundry and taking care of children are looked on as typically female tasks, while home repairs and maintenance are seen as male tasks. Wives holding a traditional gender ideology will perform more family work, the work which is traditionally associated with being female (i.e., housework, childcare, and emotion work) (Erickson, 2005). So, individuals internalize views about men's and women's proper roles and such society's prevailing gender ideologies have an effect on men's gender identity ${ }^{7}$.It sounds clear that culture lies at the bottom of men's avoidance of domestic duties. Cultural stereotypic beliefs do not only describe who women and men are, but also who they should be (Worell, 2001, p. 562). People automatically rely on gender stereotypes to perceive others. Men and women are to conform to social norms and traditional gender roles. Men are supposed to make a living to provide for their families, while women should stay at home cooking, cleaning, and taking care of children (Crespi, 2003). Men are taught to be "aggressive" and take responsibility; women are socialised to be "submissive" and "weak" (ibid., p. 5). Unfortunately, these gender stereotypes are still pervading society today. In this regard, there are certain characteristics that are associated with both men and women. Males are expected to be "controlling, selfconfident" (Worell, 2001, p. 562), “independent, adventurous, aggressive, assertive and task-oriented" (Crespi, 2003, p. 5), whereas females are supposed to be "warm, kind, and concerned for other's welfare" (Worell, 2001, p. 562), "dependent, sensitive, gentle, emotional and people-oriented" (Crespi, 2003, p. 5). Developed by Janet Spence, Robert Helmreich, and Joy Stapp (cited in Worell, 2001, p. 563), table 1 below includes the gender stereotypic traits that form the "Personal Attributes Questionnaire (PAQ)." Women are predicted to be described by feminine physical characteristics and cognitive abilities, have feminine traits and occupy feminine roles. Hence, identifying a person as male or female makes us think of them as having masculine or feminine characteristics.

\footnotetext{
${ }^{7}$ There is a world of difference between gender ideology and gender identity. Gender ideologies are "how a person identifies herself or himself in terms of marital and family roles traditionally linked to gender" (cited in Greenstein, 1996, p. 585). In this respect, Greenstein $(2000$, p. 323) makes a distinction between the two phrases pointing out that Goffman defines gender identity as "the deepest sense of what one is". According to Greenstein $(2000$,$) , "gender identities are self-definitions such$ as male or female, whereas ideologies are the elements that make up that definition. Two men who think of themselves as male (their gender identity) can have different ideas about what being male implies (their gender ideologies). One man may assert that being male means believing that domestic labor is women's work, whereas another man may feel that being male means doing an equal share of household work" (p. 323).
} 
Table 1: Gender stereotypic characteristics associated with women and men

\begin{tabular}{|c|c|c|c|c|}
\hline & Traits & Roles & PhysicalCharacteristics & Cognitive Abilities \\
\hline $\begin{array}{l}\text { Associated with } \\
\text { men }\end{array}$ & $\begin{array}{l}\text {-Active } \\
\text {-Can make decisions } \\
\text { easily } \\
\text {-Competitive } \\
\text {-Feels superior } \\
\text {-Independent } \\
\text {-Never gives up easily } \\
\text {-Self-confident } \\
\text {-Stands up well under } \\
\text { Pressure }\end{array}$ & $\begin{array}{l}\text {-Assumes financial } \\
\text { obligations } \\
\text {-Head of household } \\
\text {-Financial provider } \\
\text {-Leader } \\
\text {-Responsible for } \\
\text { household repairs } \\
\text {-Takes initiative in } \\
\text { sexual relations } \\
\text {-Watches sports on } \\
\text { Television }\end{array}$ & $\begin{array}{l}\text {-Athletic } \\
\text {-Brawny } \\
\text {-Broad-shouldered } \\
\text {-Burly } \\
\text {-Muscular } \\
\text {-Physically strong } \\
\text {-Physically vigorous } \\
\text {-Rugged } \\
\text {-Tall }\end{array}$ & $\begin{array}{l}\text {-Analytical } \\
\text {-Exact } \\
\text {-Good at abstractions } \\
\text {-Good at numbers } \\
\text {-Good at problem solving } \\
\text {-Good with reasoning } \\
\text {-Mathematical } \\
\text {-Quantitatively skilled }\end{array}$ \\
\hline $\begin{array}{l}\text { Associated with } \\
\text { women }\end{array}$ & $\begin{array}{l}\text {-Able to devote self to } \\
\text { others } \\
\text {-Aware of others } \\
\text { feelings } \\
\text {-Emotional } \\
\text {-Helpful to others } \\
\text {-Gentle } \\
\text {-Kind } \\
\text {-Understanding } \\
\text {-Warm }\end{array}$ & $\begin{array}{l}\text {-Cooks the meals } \\
\text {-Does the household } \\
\text { shopping } \\
\text {-Does laundry } \\
\text {-Is fashion conscious } \\
\text {-Source of emotional } \\
\text { support } \\
\text {-Takes care of } \\
\text { children } \\
\text {-Tends the house }\end{array}$ & $\begin{array}{l}\text {-Beautiful } \\
\text {-Cute } \\
\text {-Dainty } \\
\text {-Gorgeous } \\
\text {-Graceful } \\
\text {-Petite } \\
\text {-Pretty } \\
\text {-Sexy } \\
\text {-Soft voice }\end{array}$ & $\begin{array}{l}\text {-Artistic } \\
\text {-Creative } \\
\text {-Expressive } \\
\text {-Imaginative } \\
\text {-Intuitive } \\
\text {-Perceptive } \\
\text {-Tasteful } \\
\text {-Verballyskilled }\end{array}$ \\
\hline
\end{tabular}

Shared cultural beliefs have a lot to do with gender stereotypes. "Gender stereotypes are our beliefs about how most people view the typical man or woman" (cited in Ridgeway, 2009, p. 148). These beliefs are cultural knowledge that most people have, hence, "we expect others to judge us according to them" (ibid., p. 149). In this way, these shared cultural beliefs about gender shape our behavior and act as norms and rules for coordinating public behavior on the grounds of gender. Gender stereotypes implying gender differences are usually transformed into gender inequality. The stereotypic belief "men are from Mars and women are from Venus" is a case in point (Sollie, 2000, p. 42). It is viewed that men belong to the higher status group which is seen to be as "more proactive and genetically competent (from Mars)", while the lower status group, women, is perceived as "more reactive and emotionally expressive (from Venus)" (cited in Ridgeway, 2009, p. 149). As a conclusion, gender/sex, as a "primary cultural frame for organizing social relations" ", is highly susceptible to cultural generalizations which coordinate behavior with others (ibid., p. 147).

\section{DATA AND METHOD}

This study has uncovered the root causes of the sex-segregated division of household responsibilities in male-breadwinner families, demonstrating its association with childhood socialization. With regard to my respondents, I limited my analysis to male-breadwinner couples with young children aged up to 7 or 8 . I specifically chose this segment of the population to exclude the possibility that young children, as members of the household, take part in the household work. The spouses I met have different levels of education; some have high levels of education (PhD, MA, BA); others are illiterate. Spouses' ages range from 29 to 43. The total number of spouses I have interviewed is 90 , that is to say, 45 breadwinner couples. The sample was drawn from the 
south of Morocco. I have taken enough samples from the south region of Morocco to come up with a locally representative sample.

It is worth mentioning that data has been collected by means of two instruments: a questionnaire and a tape recorder. I started recording my data via a tape recorder. Each conversation was tape-recorded and took about 40 minutes to finish. The data were collected via face-to-face interviews and a questionnaire reminding me of all the points to come up during the interviews. I recorded about 9o conversations, but these recordings include both illiterate and literate husbands whose wives are homemakers. However, I found a problem with some respondents; they refused to have their voices recorded. That was why I felt obliged to write down their answers. I had to fill out questionnaires while I was interviewing them. During the interviews, I asked my respondents about many aspects of their personal beliefs and actions with regard to domestic work. Respondents were asked to describe various aspects of their own and their spouses' roles within the family, their relationships with children, and the effect of the dual-career family on their family relationships. The percentages of each response category were presented.

\section{RESULTS AND DISCUSSION}

This section enlightens readers on the lifestyle of Amazigh couples belonging to male-breadwinner households. Amazighs are more conservative than Arabs, that is why I preferred to shed light on them in terms of certain family life aspects. Getting involved in discussions with Amazigh single-earner couples, I came out with certain findings. The following two sections explain in what ways Amazighs are so traditional.

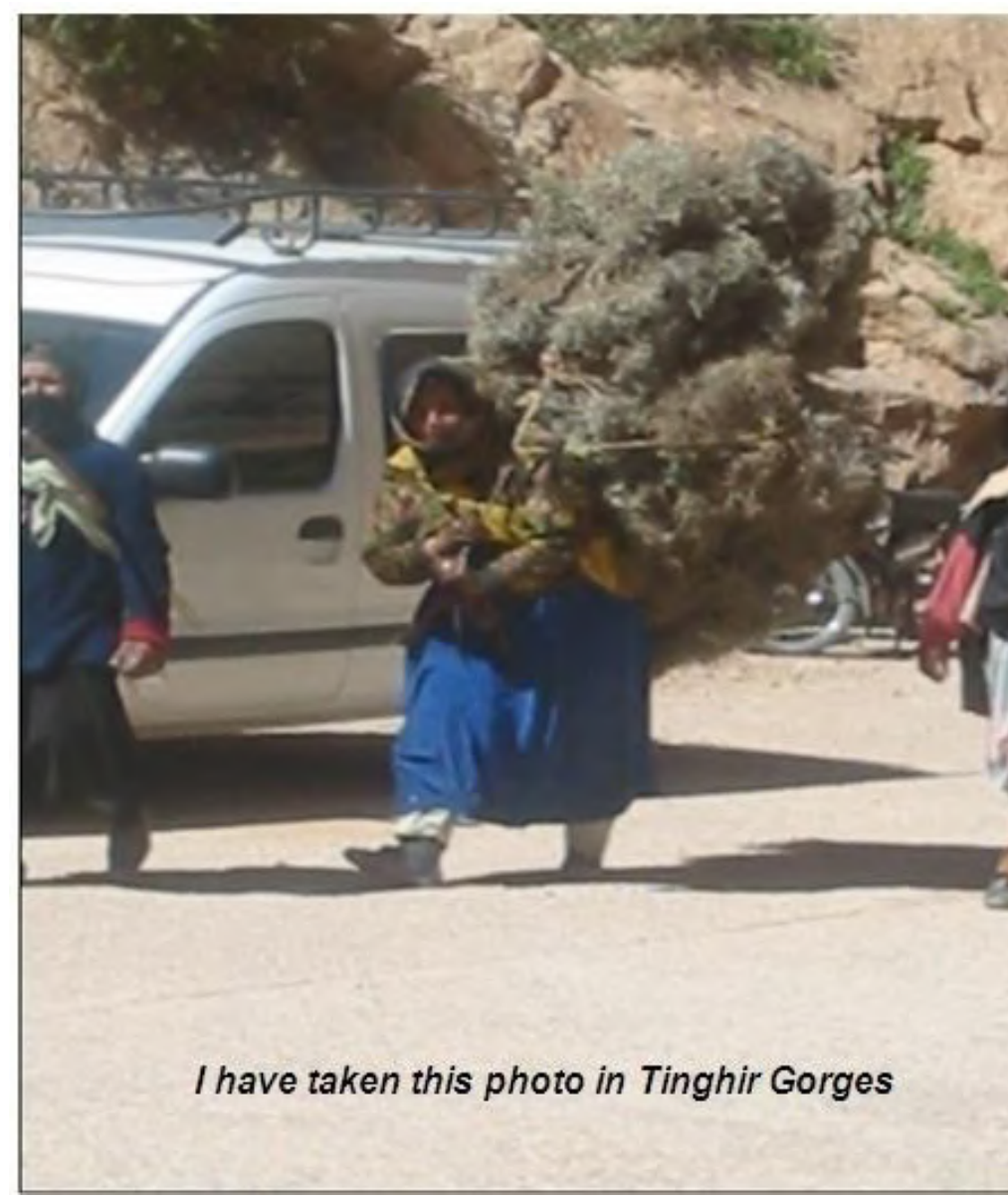

\subsection{Amazigh male-breadwinner couples}

\section{are homemakers}

Amazigh husbands and wives are so conservative that they take their ancestors as models. They follow their grandfathers' steps and copy their patterns of life. It seems as if media did not reach their place. As far as illiterate wives are concerned, I had conversations with more than 21 wives and I deduced that these wives have the same mindset. They work more than husbands. They work both inside and outside home. They not only have to carry the double burden of doing housework and taking care of children, but also have to work in fields seeding plants and keeping a close watch on them. They keep going there on a daily basis until crops grow to harvest. They wake up early in the morning to do such a hard task which takes at least 3 hours. Besides, wives lift heavy things on their backs while moving from fields to homes. What really shocked me is that the men of the area look on their wives, sisters or mothers lifting a pile of things on their backs and never do anything about it. The following picture of a Amazigh wife confirms this fact.

Note:Amazigh jobless illiterate wives do work in fields more than husbands. Men just water plants, whereas women plant seeds, pick up fruits, and lift a pile of heavy 
things on their backs from fields to their homes. According to Amazigh culture, this task is restricted to women only and it is shameful for men to help women in fields; therefore, men look on women who are loaded with heavy things. To my astonishment, men should do this task, not women, owing to their physical strength. Amazigh men rely on physically-weak women to do such a hard task. As it seems, Illiterate Amazigh women suffer more than Arab illiterate women as the former work both inside and outside home.

Amazigh wives make sacrifices and do their best to preserve their families, whereas their husbands do just little work or no work in the case of some men. These women believe that their main mission in life is to take care of children, obey their husbands and do housework. They maintain that women are created for such a function and nothing more. When I asked them whether husbands helped them at home, they got surprised by my question. They think that the task of doing housework is against their husbands' manhood. They firmly believe that housework and childcare are restricted only to women and it is shameful for a man to offer help with housework. Concerning this point, I deduced from their way of thinking that they themselves reject the idea of domestic labor sharing. They said that it was really dishonorable to see a man doing the washing up, the cooking, the laundry or the cleaning. Aicha khalil, aged 60 years old, from Khmis Dades, said "if men offer help with either household duties or children, they are women like indeed". Men lending women a helping hand at home become an object of ridicule among women themselves. When I asked them why they had such an attitude, some of them replied that Islam came up with the idea of gender roles. They believe that the division of labor has been ordained by God. Others are of the opinion that they are accustomed to doing household duties because they grew up watching their mothers and grandmothers doing likewise. They are used to the idea that men do nothing at home, but give commands or orders. Men have a great value in comparison with women. What is amazing is that these women are perfectly satisfied with their lifestyle and they are ready to make sacrifices for the sake of keeping their husbands with them.

As far as Illiterate Amazigh husbands are concerned, they are so traditional. They like to exert power over family members and take the final word on family issues. When I asked them about their lifestyle and what kind of activities they did once they were home, they answered saying that they spent hours outside home working to sponsor the family, and once they were home they ate, watched TV and slept. They have rejected the idea of labor sharing and said that housework was the job of women. They consider housework as a degrading job. From their way of speaking, I managed to see their point of view towards women. They look at women as inferior and weak creatures. Around $100 \%$ of illiterate husbands said that Islam set housework and childcare tasks for women. They said that being Muslims, they should abide by what is stated in the sacred text "Quran".

The following figure sums up all the points raised above and gives a clear image about the actual division of household tasks among illiterate single-earner couples.

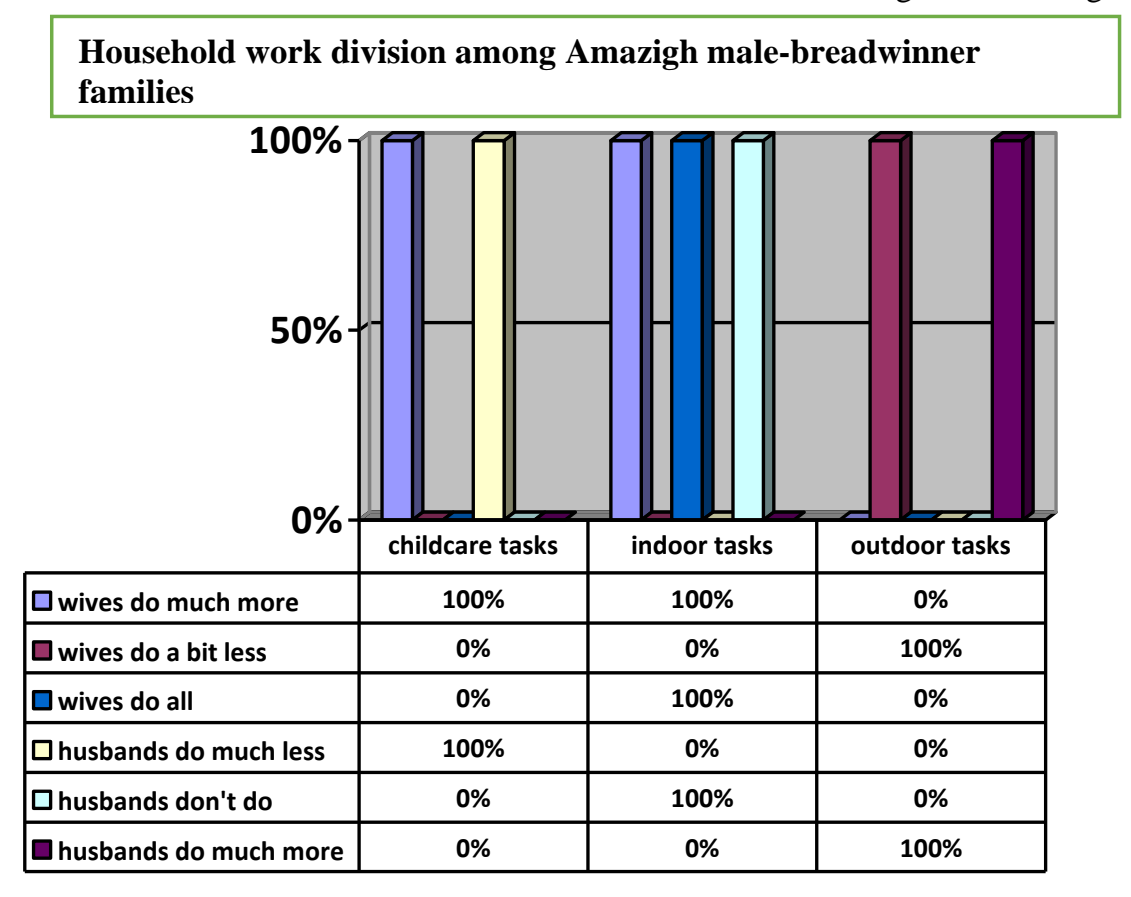

Fig.8. Percentage distribution of household tasks performed by Amazigh illiterate husbands and wives. 
Figure 8 shows that out-of-work Amazigh illiterate women do indoor tasks alone and also do a much larger proportion of childcare. Amazigh women are exclusively responsible for such traditional household tasks as cooking, cleaning, washing the dishes, doing the laundry and taking care of children. They have overall responsibility for both children and domestic chores. They also perform a bit less than their fair share of outdoor tasks than husbands, which means that they perform a great deal of outdoor tasks as well. Men's contributions tend to be limited to certain types of tasks like disciplining children, household repairs and yard work. They perform a much more than their fare share of outdoor tasks. However, out-of-work illiterate women perform the majority of yard work as it is stated above in the graph. With regard to childcare, husbands perform much less that their fare share of childcare tasks. They do not do indoor tasks at all. Thus, husbands devote less time and efforts to childcare, but more time to outdoor tasks. When asked about the reason of such unfair division of household tasks, the overwhelming majority of Amazigh women reported that religion was the major source behind the unequal division of labor, and so they were in charge of domestic duties. They said that it was religion which dictated gender roles and made each sex responsible for a certain kind of responsibilities.

\subsubsection{Educated husbands whose wives are homemakers}

Amazigh educated husbands have the same way of thinking as their fathers. In spite of being educated, they copy their fathers who set an example for the following generations. They see household labor as the job of women and thus never assist their wives at home. Personally speaking, I met a great number of employed educated men whose wives are jobless. To exemplify, I met teachers, municipality clerks, a post office manager and a postman, working in Khmiss Dades. These employed educated husbands do nothing once they are home. They have faith in traditional gender roles. Amazigh educated husbands married to homemakers are against labor sharing and therefore against women's employment; they said that men took precedence over women to have jobs and high positions in society because men are the ones who sponsor the family. They said that men sponsored the family even if the women were employed. They carried on saying that men were qualified physically to work outside home and women inside it. Thus, there is no doubt that these men support feminine domesticity and masculine breadwinning. They wish their wives to be exactly like their mothers.

Amazigh single-earner couples treat their sons and daughters differently on the basis of gender. When I asked a group of Amazigh teachers 'what kind of tasks they ask their sons and daughters to do at home', they replied that they differentiated between their sons and daughters in terms of tasks. They assign daughters the task of doing housework and sons the role of doing tasks outside home like sending them on errands. They stressed that they asked their daughters to work inside home and sons outside home. It seems quite clear that these teachers treat them differently on purpose to reinforce their gender identity. When I asked them whether they taught their sons and daughters the same principles such the sense of independence and self-reliance, they answered "yes". In replying to this question, the respondents' answers were contradictory. How can sons and daughter be both independent and self-reliant if parents give them different tasks to do and want them to be skilled in different jobs? They like their sons to be skilled in conventional male tasks and girls in conventional female ones. These husbands claim that they are democratic and fair when it comes to dealing with their offspring, which is not true. Therefore, girls grow up with a sense of weakness as if femininity carries a stigma.

Amazigh educated husbands are so conservative. For instance, Soulaiman El Mahmoudi, a teacher of History and Geography, said that if a girl leaves her hometown and goes to university, she will be spoiled and lose her morals due to her contact with boys. The result is that she will be no longer shy and will be rude instead. From my own point of view, I see that this kind of husbands is manipulative. They like to put women under their control and want them to obey their orders and never think of themselves as equal partners to men. Girls or women in general, studying at university, acquire a sense of confidence and develop a strong personality. They have their say with regard to family issues. Amazigh educated husbands do not like women of this sort. Quite the reverse, they like obedient, submissive, powerless and vulnerable women. That is why, when I was interviewing another secondary school teacher, this time of Arabic, I asked him whether his wife was educated or not. He replied happily and rapidly that his wife was illiterate. He is an educated man and he prefers to live with an uneducated wife.He wants to have his wife under his control and can achieve that only by getting married to an illiterate wife. He told me he did not want to hear the expressions such as "c'estlogique", "bien", "normalement" on the part of his wife. Moreover, when I asked a clerk working in the municipality of KhmissDades 'why he doesnot help with housework', he replied saying "you Arabs keep your ideas and attitudes to yourselves and do not bring them to our place". It was apparent from his way of speaking that he has not given and will never give a hand to his wife.

To my astonishment, some Amazigh educated husbands do not want their wives to be examined by male 
doctors. They said that they let male doctors examine their wives on condition that there were no female doctors in hospital. To make matters worse, Hassan Boudad, a teacher of science, said that "if his wife gets sick and there are just male doctors in his home town, he will travel to another big city to look for a female doctor". These husbands, like Hassan Boudad, said that they applied religion in practice; they said "Islam is not a set of thoughts and beliefs and that's it; Islam is a way of behaving and dealing with people; people should put religion into practice". These husbands excuse their behavior by misrepresenting religion which dictates nothing about this issue. According to them, male doctors should not see their wives' bodies. They forget the matter that doctors are doing their job and there is no need for such doubts. Besides, these husbands favour polygamy and make use of the prophet Mohammed (Peace Be Upon Him) to justify their deeds. They forget the fact that our prophet is the only person who can marry more than one woman owing to his justice when it comes to dealing with his wives.

\section{CONCLUSIONS}

Being educated or not, all the Amazigh husbands belonging to male-breadwinner households I dealt with were born and raised in traditional single-earner families. They have got illiterate and jobless mothers and so like to have housewives in order to do housework and rear children. They are accustomed to seeing their mothers waiting on their fathers hand and foot. They like their wives to be exactly like their mothers. The fathers of these husbands are illiterate and reject totally the idea of domestic labor sharing. Husbands grew up seeing their fathers and ancestors doing nothing at home. The result is that husbands are convinced that it is women's duty to do domestic labor. Others feel obliged not to do housework, for fear of becoming an object of ridicule on the part of the men and women of their neighborhood. According to what has been raised earlier in the literature, spouses from malebreadwinner families have traditional sex-role attitudes and prefer a single-earner family structure. Husbands model themselves after their fathers and wives model themselves on their mothers. Hence, the family structure has a lasting influence on spouses and so on their attitudes towards women's labor force participation and domestic labor. On the other hand, although most women do all the household tasks alone and do such hard task as working in fields, only a small minority of women view the division of household work as unfair. Change can take place only if the interviewed Amazigh women themselves change their viewpoints. Still, holding egalitarian values on the part of husbands to share domestic work is not enough. A more equal division of housework is only likely to happen when wives themselves feel the matter is significant and desire to change it.

\section{REFERENCES}

[1] Baxter, J. (1997). Gender equality and participation in housework: A cross-national perspective. Journal of Comparative Family Studies, 28, 220-247.

[2] Blair, S. L., \& Lichter, D.T. (1991). Measuring the division of household labor: Gender Segregation of Housework Among American Couples. Journal of Family Issues, 12, 91-113.

[3] Brines, J. (1994). Economic dependency, gender, and the division of labor at home. American Journal of Sociology, 100, 652-688.

[4] Coltrane, S. (2000). Research on household labor: Modeling and measuring the social embeddedness of routine family work. Journal of Marriage and Family, 62, 1247-1268.

[5] Crespi, I. (2003). Gender socialization within the family: A study on adolescents and their parents in Great Britain. Retrieved from https://www.iser.essex.ac.uk/files/ conferences/bhps/2003/ docs/pdf/papers/crespi.pdf

[6] Delphy, C. (1984). Close to home: A materialist analysis of women's oppression. Amherst: University of Massachusetts Press.

[7] Dodson, L., \& Dickert, J. (2004). Girls' family labor in lowIncome households: A decade of qualitative research. Journal of Marriage and Family, 66(2), 318-332.

[8] Ehrenberg, M. F., Gearing-Small, M., Hunter, M. A., \& Small, B. J. (2001). Childcare task division and shared parenting attitudes in dual-earner families with young children. Family Relations, 50(2), 143-153.

[9] Eichler, M., \& Albanese, P. (2007). What is household work? A critique of assumptions underlying empirical studies of housework and an alternative approach.Canadian Journal of Sociology, 32(2), 227-258.

[10] Erickson, R. J. (1993). Reconceptualizing family work: The effect of emotion work on perceptions of marital quality. Journal of Marriage and the Family, 55, 888-900.

[11] Erickson, R. J. (2005). Why emotion work matters: sex, gender, and the division of household labor. Journal of Marriage \& Family, 67(2), 337-351.

[12] Greenstein, T. (1996).Husbands' participation in domestic labor: Interactive effects of wives' and husbands' gender ideologies. Journal of Marriage and the Family, 58, 585595.

[13] Greenstein, T. N. (2000). Economic dependence, gender, and the division of labor in the home: A replication and extension. Journal of Marriage and Family, 62(2), 322335 .

[14] Hossain, Z., \& Anziano, M. (2008). Mothers' and fathers' involvement with school-age children's care and academic activities in Navajo Indian families. Cultural Diversity and Ethnic Minority Psychology, 14(2), 109-117. 
[15] Kamo Y. (1988). Determinants of household division of labor: resources, power, and ideology. Journal of Family Issues, 9, 177-200.

[16] Poortman, A., \& Tanja, V. (2009). Attitudes toward housework and childcare and the gendered division of labor. Journal of Marriage and Family, 71(3), 526-541.

[17] Ridgeway. C. L. (2009). Framed before we know it: How gender shapes social relations. Gender and Society, 23, 145-160.

[18] Shelton, B.A., \& John, D. (1996).The division of household labor. Annual Review ofSociology, 22, 299-322.

[19] Sollie, D.L. (2000). Beyond Mars and Venus. National Forum, 80(3), 42-45

[20] Thompson, L., \& Alex, J. W. (1989). Gender in families: Women and men inmarriage, work, and parenthood. Journal of Marriage and the Family, 51, 845-71.

[21] Worell, J. (Ed.). (2001). Encyclopedia of women and gender: Sex similarities and differences and the impact of society on gender (Vol.1). San Diego, CA: Academic Press.

[22] Yeung, W. J., Sandberg, J. F., Davis-Kean, P. E., \& Hofferth, S. L. (2001).Children's timewithfathers in intact families.Journal of Marriage and Family, 63(1), 136-154.

[23] Zick, C. D. (1996). Assessing the past and future of research on household work: A comment on Bryant's article.Family and Consumer Sciences Research Journal, 24(4), 393-400.

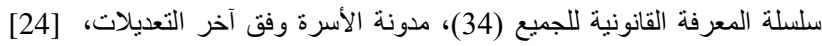

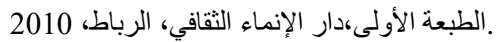

